\title{
Adrenal Cancer Pathologic Primary Tumor TNM Finding v7
}

National Cancer Institute

\section{Source}

National Cancer Institute. Adrenal Cancer Pathologic Primary Tumor TNM Finding v7. NCI Thesaurus. Code C89398.

A pathologic finding about one or more characteristics of adrenal cancer, following the rules of the TNM AJCC v7 classification system as they pertain to staging of the primary tumor 